\title{
CURRICULUM 2013 AND THE FUTURE OF ISLAMIC EDUCATION IN INDONESIA
}

Zalik Nuryana, S.Pd.I., M.Pd.I.

Pendidikan Agama Islam, Fakultas Agama Islam, Universitas Ahmad Dahlan Yogyakarta zalik.nuryana@pai.uad.ac.id

\begin{abstract}
Education curriculum change in a country is an absoluteness. Curriculum change in Indonesia, the effort of education improvement at school is a part of curriculum innovation adjusted with era development, including Islamic Education. PAI curriculum determines types and quality of education and experience that enables graduates to have global insight and curriculum development is an endless process which is performed. Efforts as performed in Indonesia is by prevailing Curriculum 2013 which is expected to become the future of Islamic Education in Indonesia. The problem raises when PAI teacher does not comprehend curriculum 2013 which becomes a refference in implementing the education. Ironically, the incomprehension occurs in a school which almost becomes K13 pilot project. Teacher is suppossed to understand and comprehend K13 start from planning, implementation, evaluation and learning of PAI. Innovation of scientific approach in PAI learning and authentic evaluation has not performed as expected. This research is aimed to know implementation of Curriculum 2013 in PAI lessons at school. It is done because K13 is expected to be the future of PAI development in Indonesia. This research is conducted at school as observation place (field research) using qualitative approach by explaining in descriptive analysis. The data collected using observation, interview, and document study which is furthemore processed and analyzed. The research result indicates that: (1) Curriculum 2013 that should be understood by PAI teacher as a refference of learning implementation has not fully understood. (2) the implementation refference of planning, implementation and evaluation of K13 on PAI lesson has not fully implemented. (3) Scientific approach and authentic assessment has not been understood and implemented by PAI teacher. This research also provides suggestion to : (1) Relevant agency to perform accompaniment and monitoring towards the implementation of K13 on PAI lesson at school. (2) Teacher of PAI should understand and implement K13 as the implementation refference, planning and evaluation that have been determined so that K13 becomes the future of Islamic Education in Indonesia.
\end{abstract}

Key words: The Implementation of Curriculum 2013, scientific approach, authentic assessment, Islamic Education Improvement.

\section{INTRODUCTION}

Education curriculum change in a country is an absoluteness. The effort of education improvement at school is a part of curriculum innovation adjusted with era development, including Islamic Education. Since curriculum is not an instant matter, thus curriculum should be flexible, dynamic and able to be developed as the condition of school, educator's characteristics, cultural and social condition of the society and by paying attention towards local wisdom (Rahmat Raharjo, 2012:1). Present Islamic education raise sharp criticisms because their incompetence in handling critical issue in social life (Sutrisno, 2006:5). This cricism emerges because Islamic education at school faces problem tha should be immediately handled so that it is appropriate with the objective of Islamic education at school. Curriculum determines the types and quality of education and experience that enable graduates to have global insight. The development of 
curriculum is an endless process to avoid obsolete curriculum left by the era develppment and life which is developed rapidly.

This research is aimed to find out the implementation of K13 at school that become pilot project in Sleman Regency. The intended implementation includes, first, PAI teacher's understanding towards the implementation refference of K13 learning. Second, PAI teacher implementation in K13 includes planning, implementation, and evaluation of Islamic religion. Third, scientific approach implementation and authentic assessment that become one of K13 characteristics.

Binti Maunah explains that in the beginning, the term of curriculum is found in statistical world. In ancient Greek Era, curriculum comes from the word of curir which means runners and curere which means a place to race.

Meanwhile, curriculum is defined as the distance that should be taken by runners (2009:1). There are two intentions that can be drawn from the definition, which are: a race distance that should be taken by runners; and it is a chairat or a rail spur in the past which is inform of a vehicle to bring an individual from the start to finish (Syafrudin et all., 2003:33). The term of curriculum as utilized in the education world that can be found in Webster Dictionary 1955 is defined as: $a$ course, especially a specified fixed course of study as in a school or college, as one leading to a degree. This definition contains a definition that curriculum is a number of lessons at school or academy that should be taken by students to achieve a level or certificate.

K13 is prevailed started in academic year 2013/2014 which fulfills two curriculum dimensions, first, curriculum is a plan and organization through objectives, content, and learning material. Second, it is a way for learning activity which is aimed to prepare Indonesian individuals so that they have life skills as faithfull, creative, innovative and affective individuals and citizens who are able to contribute in social, national life, and world civilization (Regulation of Education and Culture Minister Number 68 year 2013). K13 has some characteristics, among them are; K13 develops attitude scope, knowledge and skill. The three competence areas have different acquisition path (psychological process). The attitude is obtained through activities of receiving, implementing, respecting, reflecting and practicing. Knowldege is obtained through activities of remembering, understanding, implementing, analyzing, evaluating, and creating. 
Skills obtained through the activities of observing, trying, reasoning, presenting and creating; (2) Scientific approach. Knowledge is obtained through scientific to push learners' competence in creating contextual work, both individual or group. Thus it is suggested that they use project and problem based learning approach; (3) authentic assessment. Authentic assessment is a process of collecting, reporting and using information on students' learning result by implementing assessment principles, continous implementation, authentic, accurate and consistent evidences as public accountability. Assessment which is implemented includes significant measurement on learners' study output for attitude, skill and knowledge scope. Authentic assessment is an assessment process which involves some performance measurement forms which reflect students' learning, achievement, motivation and attitude as the learning material (Regulation of Education and Culture Minister Number 66 Year 2013).

Curriculum change in order that education dynamization and to answer national problems is a real action done by the government in order to improve education system in Indonesia. By legalizing K13 (Curriculum 2013) through President Regulation number 32 year 2013 Indonesia has legally implemented K13 including Islamic Religion. The change should be socialized widely and quickly in all parties who have direct interest with education at schools or the others. Especially teacher as the spearhead in K13 implementation. The paradigm moves education process from teaching to learning. Learning is a process of learners' interaction with teacher and study source in a learning environment. The learning process should be planned, implemented, assessed, and supervised so that it is implemented effectively and efficiently. The implementation of K13 is expected to be the future of Islamic Religion in Indonesia.

Characteristics of PAI learning and character of each set of education unit is related to Graduates Competence Standard and Content Standard. Graduates Competence Standard provides conceptual framework on learning target that should be achieved. Content standard provides conceptual framework on learning activity and learning is decreased from competence level and material scope room. The details of attitude gradation, knowledge and skill can be seen in the following table: 


\begin{tabular}{|l|l|l|}
\hline \multicolumn{1}{|c|}{ Attitude } & \multicolumn{1}{|c|}{ Knowledge } & \multicolumn{1}{c|}{ Skill } \\
\hline Accepting & Remembering & Observing \\
\hline Implementing & Understanding & Asking \\
\hline Respecting & Applying & Trying \\
\hline reflecting & Analyzing & Reasoning \\
\hline Practicing & Evaluating & Presenting \\
\hline & & Creating \\
\hline
\end{tabular}

Figure 1. Attitude Gradation, Knowledge and Skill

Islamic religion Education in $\mathrm{K} 13$ as in Regulation of Education and Cultural Minister number 68 year 2013 has characteristics, such as : (1) PAI is a lesson developed from Islamic education involving al-Qur'an, Hadits, aqidah,morals, jurisprudence (fiqih) and history of Islamic civilization; (2) if it is seen from the education content, PAI is a main lesson that becomes a component which cannot be separated from another lesson which is aimed to develop moral and personality of learners; (3) PAI lesson is given to shape learners who are faithful and cautius towards Allah SWT, have noble character (morals), and have sufficient knowledge on Islam, especially the source of teaching and other Islamic aspects. Thus, it becomes the provision to learn various scientic field or lessons without being affected by negative impact that may be raised by certain knoledge and lesson; (4) PAI is a lesson which does not only drive learners to master various Islamic studies, however, PAI more emphasizes on how learners are able to master the Islamic study and practice it in their daily life within the society. Therefore, PAI and Character do not only emphasize on cognitive aspect, but also affective and psychomotoric aspects; (5) In general, PAI is based on the provisions exist on two Islamic teaching main source as in Al-Qur'an and Hadits of Muhammad SAW Prophet. It is also done through diligence method (aqli theorem), theologians are able to develop it in more detail in jurisprudence study and other diligence results; (6) The fnal objective of PAI lesson is to shape learners who have noble morals (noble characters) as the main mission of Nabi Muhhamad who is dispatched in the world. It does not mean that Islamic education does not pay attention to physical education, mind, knowledge or other 
practical aspects. However, the intention is that Islamic education pays attention to moral education aspects and another.

This research focusses on; (1) PAI teacher's understanding towards the learning implementation in K13; (2) PAI teacher implementation in K13 involves planning, implementation, and evaluation of Islamic learning evaluation; (3)scientific approach and authentic assessment implementation. This problem is interesting to observe in order to know how far the implementation of K13 in Islamic Education whic is started from planning, implementation and evaluation of Islamic education at school. The Implementation of K13 is not implemented in all schools but only schools that become pilot project of the implementation of K13. It is also interesting, because schools that becomes the model of K13 are they who have good accreditation and are categorized as independent school.

As a research in Islamic education, the research result is expeted to be useful, first, providing the description of K13 implementation at school. Third, being one of teacher's motivations to increase their profession competence so that the education in Indonesia is more sophisticated. Fourth, as one of further research refferences with wider scope.

\section{METHOD}

This researchis aimed to know the implementation of K13 at school. This research is done in Sleman Regency, Special Region of Yogyakarta by using Turi State 2 Junior High School and Kalasan State 3 Junior High School as the research place. Interview, Observation, and document study is done by both schools. This research is done in August-October 2016. This research is a qualitative research by using descriptive analysis to find out the effect of curriculum 2013 implementation towards PAI teacher learning from the process of planning, implementation and evaluation of Islamic Education learning at Turi State 2 Junior High School and Kalasan State 3 Junior High School. The main sujects of this reseach are headmasters, PAI teachers and students of Grade VII and VIII.

The interview with PAI teacher of both schools contains of steps prepared in order to implement Curriculum 2013 on learning plan making, MGMP PAI, Trainings to support the implementation of Curriculum 2013, obstacle in the implementation of Curiculum 2013 starts from planning, process, and learning 
evaluation. Interview with the head of MGMP PAI of Sleman Regency concerning MGMP policy in the implementation of Curriculum 2013 at school.

The researcher uses data analysis technique by describing and analyzing all things that become the focus of this research concering the implementation of Curriculum 2013 towards PAI teacher's learning starts from the process of planning, implementation and evaluation of Islamic Education learning at Turi State 2 Junior High School and Kalasan State 3 Junior High School. The analysis process is started by analyzing all data obtained from interview result, field notes, and documentation by organizing the data in categories, elaborating them into units, performing synthesis, organizing into pattern, selecting which one is important to learn, and making conclusion so that it is eas to be understood by themselves or other people.

\section{RESULT AND DISCUSSION}

\section{RESEARCH RESULT}

Planning is the intial step that should be prepared by PAI teacher in the implementation of Curriculum 2013 at school, including Turi State 2 Junior High School and Kalasan State 3 Junior High School. The components are sylabus and Lesson Plan. The role of teacher in developing the learning that is started by making a good lesson plan influences the learning process. This ability requires proffesionalism of PAI teacher. As the Government regulation, PAI teacher at Turi State 2 Junior High School, Sri Sulistyowati, S.Ag and Kalasan State 3 Junior High School, Sri Maryani, S.Ag are proffessional teachers. It is proven by professional teacher certificate and they who get proffessional support. The research result is presented in sequence from the implementation of K13 in PAI which is started from planning, implementation and evaluation of learning.

In the planning of K13 learning is included in PAI at Kalasan State 3 Junior High School, the syllabus is prepared by the government. Therefore, the task of PAI teacher is to develop Lesson Plan. The government's objective to prepare syllabus is so that teachers are able to develop Lesson Plan as the signs that have been determined. Besides syllabus, the government also make students and teacher's guideline book to enable the learning process and provide teacher's 
room to develop their creativity in teaching. Thus, it is found the similarity of syllabus at each school. In the arrangement of Lesson Plan, PAI Teachers of Turi State 2 and Kalasan State 3 Junior High School have arranged Lesson Plan as the Curriculum 2013 as written in the Regulation of Education and Cultural Minister number 103 year 2014. The document which is given to the researcher has contained of K13 in the discussion.

In the learning implementation through class observation, the researcher finds that learning is designed to provide learning experience that involves mental and physical process through interaction among learners, between learners and teacher, environment and other learning sources in order to achive Basic Competence $(\mathrm{KD})$. The intended learning experience can be manifested through the use of various learning approach which is centerred on learners. Learning experience contains of life skill that should be mastered by learners. Learning which is implemented PAI teachers at Turi State 2 and Kalasan State 3 Junior High School refers to technical instruction issued by the government by using scientific approach in PAI lesson.

In the learning evaluation, assessment is a process of collecting information/evidence through measurement, interpretation, and description of measurement result evidences. The word Authentic in Indonesian Dictionary is defined as believe, real, valid and reliable. Authentic assessement reflects real world problem, not school world which uses holistic methods and criteria to reflect knowledge, skill and attitude. The researcher performs observation and teacher document study. It can be said that PAI teacher has used authentic evaluation, however it has not fully implemented.

\section{DISCUSSION}

The implementation of K13 implemented in Turi State 2 and Kalasan State 3 Junior High School can be expectation and the achievement of future PAI in Indonesia. The concept of K13 that emphasizes on attitude, knowledge, and skill covered by scientific aproach and authentic assessment in the learning process is expected to be able to become solution of some Islamic education problems in Indonesia.

The teacher's qualifications which are found can be seen from the table below: 


\begin{tabular}{|l|ll|}
\hline \multicolumn{2}{|c|}{ Teacher } \\
\hline SMP N 2 Turi & $\begin{array}{l}\text { 1. } \\
\text { 2. }\end{array}$ & ags government employee status. \\
\hline SMP N 3 & 1. & has honorary teacher status \\
Kalasan & 2. & is still young \\
\hline
\end{tabular}

Figure 2. Qualification of PAI teacher

Educator factors also become crucial problem in the implementation of K13. In the past, it lighters the teachers because they don't have to make syllabus. Actually, it requires extra competence to arrange Lesson Plan and many evaluation documentations because they use authentic assessment. PAI teachers should be trained with Communication Information Tecnology (CIT) that supports the implementation of K13. Teachers' age also influences the planning process and learning evaluation.

In the implementation of K13, teachers have not fully understood the concept of K13. It affects the learning implementation starts from planning, process implementation and evaluation. The result of observation and document study can be seen in the following table:

\begin{tabular}{|c|c|}
\hline & PAN \\
\hline $\begin{array}{lll}\text { SMP } & \text { N } 2 \\
\text { Turi } & & \end{array}$ & $\begin{array}{l}\text { 1. The content structure of Lesson Plan component, of the four Lessons } \\
\text { observed by the researcher, it is found that one of Lesson Plans has different } \\
\text { structure component, which is Lesson Plan on migrate to Madinah is a } \\
\text { glorious story. The difference is that core competence is abolished. } \\
\text { Reffering in the guideline of Lesson Plan organizing that basic competence } \\
\text { and indicator is written after core competence. The writing between } \\
\text { learning method and learning steps has also not appropriate. Lesson Plan on } \\
\text { the development of science in Abbasiyah era writes scientific method, direct } \\
\text { and cooperative teaching. Whereas, the writer finds that learning steps use } \\
\text { discussion method and video comment. } \\
\text { The appropriateness between achievement indicator and learning objective. } \\
\text { Writing an achievement indicator is a requirement in organizing Lesson } \\
\text { Plan. In lesson plan on permitted (halal) and forbidden (haram) food, PAI } \\
\text { teacher of Turi State } 2 \text { Junior High School has not written achivement } \\
\text { indicators. In Lesson Plan on knowledge science development during } \\
\text { Abbasiyah era, it is written two indicators, which are learning the history of } \\
\text { knowledge development until Abbasiyah era and constructing the hisotry of }\end{array}$ \\
\hline
\end{tabular}




\begin{tabular}{|c|c|c|}
\hline & 3. & $\begin{array}{l}\text { science until Umayah and Abbasiyah era for daily life. Writing two } \\
\text { indicators and five learning objectives. Thus it should be written in detail so } \\
\text { that the indicator and objective of learning can be appropriate. } \\
\text { Assessment which is put in Lesson Plan at least involves Spiritual, Social, } \\
\text { Knowledge and Skill assessment. Two of four Lesson Plans have presented } \\
\text { them clearly, however the other two Lesson plans presents the development } \\
\text { of science during Abbasiyah era and migration to Madinah as a glorious } \\
\text { story. PAI teacher only writes the assessment technique without writing the } \\
\text { detail for spiritual, social, knowledge and skill. }\end{array}$ \\
\hline $\begin{array}{lll}\text { SMP } \quad N & 3 \\
\text { Kalasan } & \end{array}$ & 3. & $\begin{array}{l}\text { Lesson plan content structure of four observed lesson plans, it is found that } \\
\text { there is only one Lesson Plan which component is appropriate with the } \\
\text { guideline, such as Lesson Plan on al-Khulafaur, ar-Rasyidun. The lesson } \\
\text { plan imitates Allah's angels adherence. It suddenly encloses main material } \\
\text { after the identity of Lesson Plan which within is written the main } \\
\text { material.Both Lesson plans on life becomes more peaceful with sincere, } \\
\text { patient, and forgiving and migation to Madinah is a glorious story ommit } \\
\text { the component of KI. } \\
\text { The inapropriateness between indicator and learning objective is also found } \\
\text { in Lesson Plan on imitating Allah's angels adherence. Four indicators are } \\
\text { written in Lesson Plan and the learning objectives explain the seven } \\
\text { learning objectives. The inapropriateness between learning media and steps } \\
\text { are also found in Lesson plan on imitating Allah's angels adherence. It is } \\
\text { written video and songs on angels, however, the learning activity is only the } \\
\text { benefit of video. } \\
\text { Inapropriateness is found in the assessment which is written by PAI teacher } \\
\text { of Kalasan State } 3 \text { Junior High School. Only lesson plan on living more } \\
\text { peaceful sincerely, patiently and forgiving that write detail assessment of } \\
\text { the spiritual, knowledge and skill attitude assessment. Lesson Plan on al- } \\
\text { Khulafaur ar-Rasyidun only writes that tasks, observation, portfolio and } \\
\text { test. While Lesson Plan on imitating Allah's angels adherence only writes } \\
\text { discussion observation, let's practice and task. }\end{array}$ \\
\hline
\end{tabular}

Figure 3. Result of Lesson Plan Research

The difference found in both schools on lesson plan is on the understanding of the components, plot, and evaluation writing which results in different Lesson Plan. It influences the process and evaluation of learning. Planned learning plan in Lesson Plan should become a good learning design. PAI 
teachers have not fully understood what is desired in K13. Thus, the lesson plan which is presented seems to copy and paste from another school.

Further result concerning the learning result concerning the learning process obtained through observation can be seen in the following table:

\begin{tabular}{|c|c|}
\hline & LEARNING IMPLEMENTATION \\
\hline SMP N 2 Turi & $\begin{array}{l}\text { 1. Scientific approach in Curriculum } 2013 \text { development is expected to } \\
\text { maximize students' comprehensive understanding on Islamic Education, } \\
\text { however, the implementation is monotonous. PAI teachers are focussed } \\
\text { on video and discussion. Various learning method applications have not } \\
\text { seemed been understood, thus the learning seems boring. } \\
\text { 2. Two-ways communication between students and teachers should be } \\
\text { kept. From the observation result, students seem indifferent towards the } \\
\text { learning. Curriculum } 2013 \text { emphasizes on moral planting, however the } \\
\text { learning is oriented on knowledge. An expected attitude emerges in } \\
\text { Curriculum } 2013 \text { which has lack of attention given by teachers. } \\
\text { 3. Scientific approach needs relative long time. Random divisions of } 3 \\
\text { hours becomes the teachers' obstacle. Finally the teachers ask students } \\
\text { to learn quickly in old class conditioning with limited time, thus the } \\
\text { planned time allocation does not run optimally. } \\
\text { 4. In the reflection of questioning, many students ask textual questions as } \\
\text { written in the tex book. "Wild" and irrelevant questions may emerge, } \\
\text { such as the examples of alcoholic beverages. Some students answer ice } \\
\text { block. As a result, all of their classmates laugh at them. }\end{array}$ \\
\hline $\begin{array}{lll}\text { SMP N } & 3 \\
\text { Kalasan } & & \end{array}$ & $\begin{array}{l}\text { 1. According to the researcher, PAI teachers' classroom mastery is good. } \\
\text { The learning implementation is carried out as the guideline because it } \\
\text { refers to teacher and students' textbook. However, it is found some } \\
\text { things in the appropriateness between Lesson Plan and learning } \\
\text { implementation, such as PAI teachers are focussed on monotonous } \\
\text { video watching model, discussion, and presentation. Scientific learning } \\
\text { steps have also passed by PAI teachers of Kalasan State } 3 \text { Junior High } \\
\text { School although the lesson plan component as written in the Lesson Plan } \\
\text { is less appropriate. } \\
\text { 2. The learning implementation is reduced to } 10 \text { minutes before the bell } \\
\text { rings. It is used to perform dhuha prayer in congregation (berjamaah). It } \\
\text { is less appropriate if it is seen from the learning process, however, on the }\end{array}$ \\
\hline
\end{tabular}




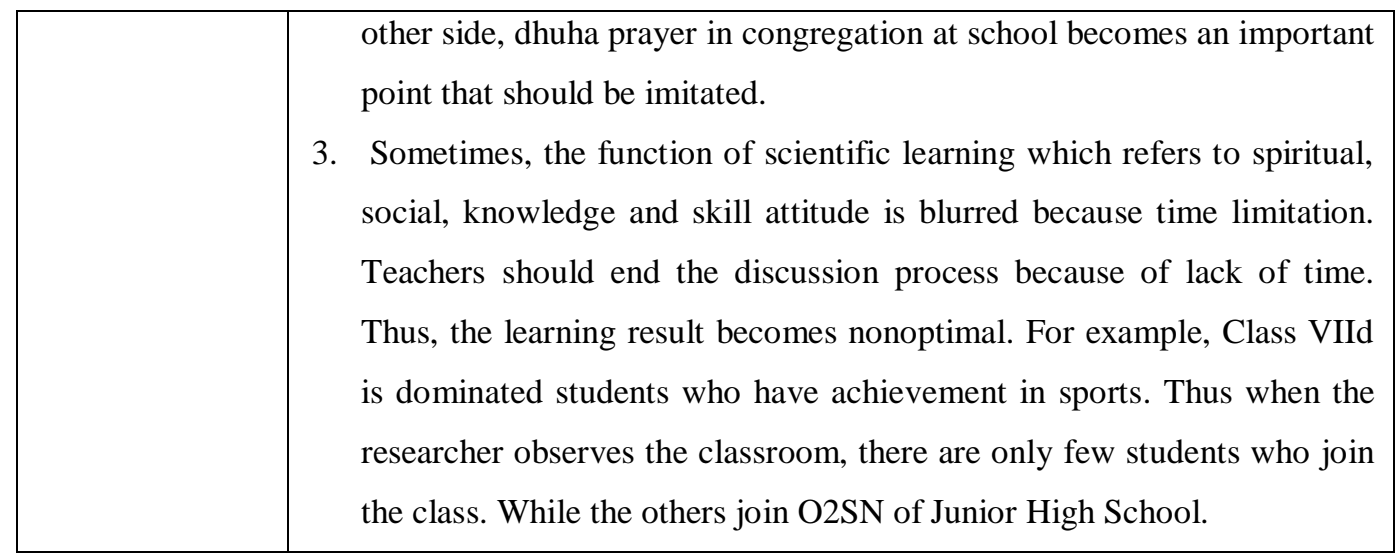

Figure 4. The Result of Learning Process Research

The learning process which is carred out by teachers by using K13 is monotonous and boring. Scientific process should becomes life class, but the teachers perform the opposite. This stage requires teachers' creativity in packaging PAI learning so that it becomes more meaningful. The learning only seems fullfilling scientific processes, thus the objective of learning material does not touch learners. The learning time is wasted for scientific process. As a result, PAI teachers ignore the material and core of learning. If it occurs continously, Islamic education loses of its Islamic value.

Finnaly, it is related to authentic assessment. Authentic evaluation that becomes one of special characteristics of Curriculum 2013 cannot also be performed optimally. The line of planning, process and evaluation of learning is a series that cannot be separated. Inapropriate planning will have impact on process and evaluation of learning. In this research, the result of authentic evaluation of each school can be seen in the following table.

\begin{tabular}{|c|c|}
\hline & LEARNING EVALUATION \\
\hline $\begin{array}{lr}\text { Turi } & \text { State } 2 \\
\text { Junior } & \text { High } \\
\text { School } & \end{array}$ & $\begin{array}{l}\text { The author only gets one assesment sample as written in the Lesson Plan. } \\
\text { However, authentic assessment refers to comprehensive assessment } \\
\text { process. This assessment demands teachers to be more careful in assessing } \\
\text { students, thus the evaluation has not been seen in the learning. More and } \\
\text { detail documents require extra carefullness so that the result is objective. }\end{array}$ \\
\hline $\begin{array}{lr}\text { Kalasan } & \text { State } 3 \\
\text { Junior } & \text { High } \\
\text { School } & \end{array}$ & $\begin{array}{l}\text { Evaluation in form of authentic assessment has not been implemented } \\
\text { comprehensively. Based on the sample and document obtained by the } \\
\text { researcher, instrument and assessment has been able to perform but it is } \\
\text { only a sample. It means that it needs special attention on this authentic }\end{array}$ \\
\hline
\end{tabular}


Figure 5. Result of Learning Evaluation Research

It can be seen from the result that authentic evaluation has not been implemented. We can imagine that students who are assessed has not utilized correct procedures. It can be an education malpractice. The evaluation should be an instrument to see how far the learning is successfull. However, it is not done as the prevailed procedure. It becomes collective reflection for a commitment that many things should be improeved in our Islamic education.

\section{CONCLUSION AND SUGGESTION}

\section{Conclusion}

Curriculum that should be understood by each education actors as the basis of learning development and manifest national goals. Curriculum 2013 that should be understood by PAI teachers as the refference of learning implementation has not fully understood. The learning is carried out carelessly. It certainly becomes our attention that Islamic education responsibility is our responsibility. This understanding will become an embryo of the success of K13 implementation in PAI lesson.

The implementation reference which contains of planning, process, and evaluation of learning is important thing that should be done so that Islamic education in Indonesia is equal. This reference should be implemented by each PAI teacher. If it is not implemented, the component will not be appropriate. Teacher should really understood each component starts from the planning, what should be implemented and made in this process. What steps are done and implemented in the learning process but they do not ignore the PAI content so that the process runs smoothly as the instruction and material of PAI that can be understood well by the students.

Scientific approach and authentic assessment should be understood and implemented by PAI teachers. The procedure and technical instructions are available for PAI in K13, so that the teachers should understand and implement it. As a consequence, the education is carried out within the scope which is made. Scientific approach which is implemented well will result in a good learning and be assessed comprehensively with authentic assessment. If both do not carried out 
well, Islamic education will only run as it is. It should be avoided that Islamic education is carried out aimless.

\section{Suggestions}

Based on the conclusion and research result on the implementation of PAI in $\mathrm{K} 13$ as the future of Islamic education in Indonesia, it is suggested that:

First, the implementation of K13 requires support by all parties, especially relevant agency for accompaniment and monitoring towards it on PAI lesson before it is implemented in all schools. This accompaniment will be very beneficial because there are some limitations and differences of PAI teachers' understanding on K13.

Second, teachers should understand and implement K13 on PAI lesson as the implementation reference which involves planning, implementation, and evaluation that have been made. This comprehensive understanding brings PAI to a determined objective. Good learning planning will influence a good learning process, then a good process will influence the learning evaluation implementation. Scientific approach can be assessed well using authentic assessment so that PAI teachers should understand it.

Third, through various trainings carried out by relevant agencies, institutes or schools, teachers should be motivated to develop themselves in order to fullfill competence as teacher. This competence will influence the implementation of education in Indonesia. A great teacher will create great students who furthermore becomes this nation's struggle generation cadre.

\section{REFFERENCES}

Abdurrahman, Dudung, Pengantar Metode Penelitian Sejarah, Yogyakarta: Galang Press, 2000. Abidin Ibnu Rusn, Pemikiran Al-Ghazali Tentang Pendidikan, Yogyakarta: Pustaka pelajar.1998. Arikunto, Suharsimi, Prosedur Penelitian Suatu Pendekatan Praktek, Jakarta:Rineka Cipta, 2006. Hadi, Sutrisno, Metodologi Research, Untuk Penulisan Skripsi, Tesis, dan Disertasi, Yogyakart: Andi Offset, 2004.

Lathifah, Eva, Implementasi Kurikulum Tingkat Satuan Pendidikan(KTSP) di SMA N Kabupaten Brebes, tesis Fakultas Ilmu Sosial dan Ilmu Politik Universitas Indonesia, 2011.

Lexi J. Moleong, Metode Penelitian Kualitatif, Bandung: PT. Remaja Rosda Karya, 2000.

Mida Latifatul Muzamiroh, Kupas Tuntas Kurikulum 2013 Kelebihan dan Kekurangan Kurikulum 2013, Jakarta:Kata Pena, 2013.

Mualimin, Mat, Implementasi Kurikulum Pendidikan Agama Islam di SMPN 1 RSBI Kota Magelang, tesis Studi Islam IAIN Walisongo Semarang, 2012. 
Muhaimin dkk, Pemgembangan Model Kurikulum Tingkat Satuan Pendidikan pada Sekolah \& Madrasah, Jakarta:PT Raja Grafindo Persada.2008.

Mulyasa, Kurikulum Tingkat Satuan Pendidikan, cet. Ke-2, Bandung : PT. Remaja Rosdakarya, 2007.

Pengembangan dan Implementasi Kurikulum 2013, Bandung : PT Remaja Rosdakarya, 2013.

Permendikbud no 65 tahun 2013 tentang Standar Proses

Permendikbud no 66 tahun 2013 tentang Standar Penilaian Pendidikan

Permendikbud no 68 tahun 2013 tentang Kerangka Dasar dan Struktur Kurikulum Sekolah Menengah Pertama/Madrasah Tsanawiyah

Permendikbud no 81A tahun 2013 tentang Implementasi Kurikulum 2013

Raharjo, Rahmad, Inovasi Kurikulum Pendidikan Agama Islam : Pengembangan kurikulum dan pembelajarannya, Yogyakarta: Magnum Pustaka, 2010.

Pengembangan dan inovasi Kurikulum : Membangun generasi Cerdas, dan Berkarakter untuk kemajuan Zaman, Yogyakarta: Baituna Publishing, 2012.

Rosyadi, Khoiron, Pendidikan Profetik, Cet. Ke-1, Yogyakarta : Pustaka Pelajar. 2004.

S. Nasution, Asas-Asas Kurikulum, Jakarta: Bumi Aksara, 1994.

Software KBBI- Kamus Besar Bahasa Indonesia v1.1.

Subandijah, Pengembangan dan Inovasi Kurikulum, Jakarta:Raja Grafindo Persada,1993.

Sugiyono, Metode Penelitian Administrasi, cet. Ke-9, Bandung: Alfabeta, 2002.

Sukandararumidi, Metode Penelitian Petunjuk Praktis Untuk Penelitian Pemula, Gajah Mada University Press, 2002.

Sutrisno, Revolusi Pendidikan di Indonesia : Membedah Metode dan teknik Pendidikan Berbasis Kompetensi, Yogyakarta: Ar-Ruzz, 2006.

Uhbiyati, Nur, Ilmu pendidikan Islam, Cet. Ke-1, Bandung : Pustaka Setia.1997. 